\title{
The Effect of Clinical and Radiological Features on Prognosis in the Top of The Basilar Syndrome
}

\author{
Baziller Tepe Sendromunda Klinik ve Radyolojik Bulguların Prognoz Üzerine Etkisi
}

\section{Zeynep Özözen Ayas ${ }^{1}$, Dilcan Kotan ${ }^{2}$, Kiyasettin Asil ${ }^{3}$}

${ }^{1}$ Eskişehir City Hospital, Department of Neurology, Eskişehir, Turkey

${ }^{2}$ Sakarya University Faculty of Medicine, Department of Neurology, Sakarya, Turkey

${ }^{3}$ Sakarya Training and Research Hospital, Department of Radiology, Sakarya, Turkey

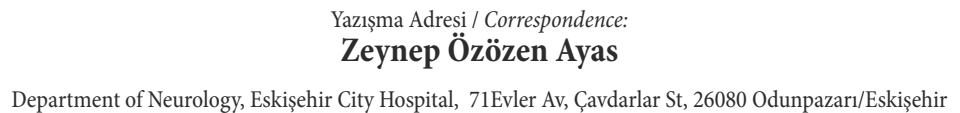

Department of Neurology, Eskişehir City Hospital, 71Evler Av, Çavdarlar St, 26080 Odunpazarı/Eskişehir T: +905059039605_ E-mail : zozozen@hotmail.com

Geliş Tarihi / Received : 13.05.2021 Kabul Tarihi/Accepte: 08.09.2021

Orcid :

Zeynep Özözen Ayas https://orcid.org/0000-0002-9302-5543

Dilcan Kotan https://orcid.org/0000-0002- 3101-4742

Kiyasettin Asil https://orcid.org/0000-0001-6966-5076

( Sakarya Tip Dergisi / Sakarya Med J 2021, 11(3):639-646 ) DOI: 10.31832/smj.937034

\footnotetext{
Öz

Objective The 'top of the basilar syndrome' (TOBS) may occur when an embolus impacts in the distal basilar artery. We aimed to investigate the relationship between the clinical, radiological parameters of TOBS, its prognosis, and mortality rates, in Sakarya, Turkey.

Materials Age, sex, presenting symptoms, National Institutes of Health Stroke Scores (NIHSS), infratentorial infarct volume (IIV), supratentorial infarct volume (SIV) lenght of stay and Methods (LOS) in neurology clinic and intensive care unit (ICU), the duration of mechanical ventilation (MV) and mortality were recorded.

Results Thirty-one patients (18 female,13 male) with diagnosed TOBS were included. The frequency was $2.2 \%$ among 1379 patients within $2,5 y e a r s$. The mean age was $69.0 \pm 12$.1 years. According to NIHSS, 11 (35.5\%) patients had mild stroke, 16 (51.6\%) moderate, and 4 (12.9\%) severe stroke. The mean IIV was $8.84 \pm 10.44 \mathrm{~mm} 3(0.17$ $33.88)$, SIV was $15.11 \pm 22.32 \mathrm{~mm} 3(0.11-87.91)$. The average LOS in neurology clinic was $6.0 \pm 3.6$, in ICU was $40.8 \pm 40.3$ days. Twenty-one (67.7\%) patients needed to be in an ICU. Patients admitted to the ICU had significantly higher decreased level of consciousness (DLC) and visual abnormalities, NIHSS, IIV. 13/21 (61.9\%) patients admitted to the ICU required MV. The mean duration of MV was 33.8 \pm 45.3 days. DLC, ataxia, visual abnormalities as an initial symptoms, NIHSS, IIV were higher among patients who required MV compared with who did not. The mortality rate was $32.3 \%$. NIHSS, LOS in clinic and ICU, the duration of MV of patients who died were statistically higher.

Conclusion : It is important to determine effective parameters in order to prognose TOBS which is a rare stroke syndrome.

Keywords Basilar artery; Prognosis; Mortality
}

Abstract

Amaç Koronavirüs hastalı̆̆ 2019 (COVID-19), solunum ve gastrointestinal sistem bozukluklarına ek olarak nörolojik bozukluklara da neden olabilir. Bu çalı̧mada COVID-19 hastalarında nörolojik semptomların sıklğı ve klinik korelasyonlarının araștırılması amaçlandı.

Gereç ve Hastaların yașı, cinsiyeti, bașlangı̨c semptomları, National Institutes of Health Stroke skorları (NIHSS), infratentorial ve supratentorial enfarkt hacimleri, nöroloji klinik ve yoğun bakım

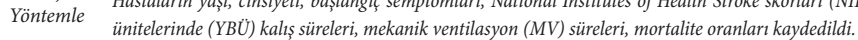

Bulgular BTS tanısı almıs 31 hasta (18 kadın, 13 erkek) alındı. Hastalık 2,5 yıl içinde 1379 inme hastast içinde \%2,2 oraninda görüldü. Hastaların yas ortalaması 69,0冈12,1 (42-97) idi. NIHSSye göre

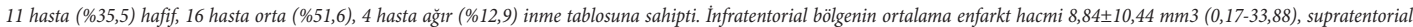

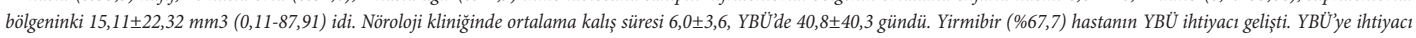
olan hastalarm bilinç değisiklĭgi ve görme bozukluğu ile bașvuru oranı, NIHSS, infratentorial enfarkt hacmi istatistiksel olarak anlamlı oranda yüksekti. YBÜ’ye giren hastaların 13/21'inde (\%61,9) MV ihtivacı gelisti. Ortalama MV'da kalıs süresi 33,8土45,3 gündü. MV ihtiyacı olan hastalarda olmavanlara göre bilinc değisikliği, dengesizlik, görme bozukluğu ile basvuru, NIHSS, infratentorial enfarkt hacmi istatistiksel olarak anlaml oranda yüksekti. Mortalite oranı \%32,3'tü. Mortal seyreden olguların NIHSS, nöroloji kliniği ve YBÜ yatış süreleri, MV gün sayısl istatistiksel olarak anlaml oranda yüksekti. 


\section{INTRODUCTION}

Basilar artery occlusion comprises around 1-4\% of all ischemic cerebrovascular diseases. The top of the basilar syndrome' (TOBS) is a description of symptoms and signs that may occur when an embolus impacts in the distal basilar artery, resulting in bilateral ischemia of upper brainstem structures and of the posterior cerebral artery territories. ${ }^{1}$ Alteration of consciousness, amnestic states, hallucinations, involuntary movements, visual abnormalities, altered pupillary responses, supranuclear paresis of vertical gaze, ptosis or eyelid retraction can be signs of TOBS.

TOBS are found at a lesser frequency than the other cerebrovascular occlusive artery disease. There is a limited literature about TOBS. ${ }^{2-4}$ Most of the reports were posterior circulation and basillar artery. ${ }^{5-7}$ No study has yet investigated the certain frequency of the disease. In this study, we aimed to investigate relationship between clinical and radiological parameters, prognosis of TOBS and mortality, which are known to be rare, in Sakarya city, Turkey.

\section{MATERIALS and METHODS}

In this descriptive study, we retrospectively reviewed 1379 patients with stroke between February 1, 2015 and July 1, 2017 in our center. Thirty-one patients meeting the detailed inclusion criteria of the study, who were diagnosed with TOBS and admitted to the hospital, department of neurology for examination and treatment were included in the study. Age, sex, presenting symptoms, premorbid medical histories (hypertension (HT), diabetes mellitus (DM), coronary artery disease (CAD), congestive heart failure $(\mathrm{CHF})$, cerebrovascular disease (CVD), atrial fibrillation (AF) were recorded. Also, we recorded National Institutes of Health Stroke Scores (NIHSS), lenght of stay (LOS) in neurology clinic and intensive care unit (ICU), the duration of mechanical ventilation (MV), mortality. The results of all tests and studies performed to determine stroke, which included CT and/or MRI.
Localization of infarct seperated two groups: infratentorial and supratentorial areas. Infarct volumes were measured using the hyperintense lesion on diffusion MRI area and hypointense lesion on CT by radiologist. Brain CT was performed with Toshiba Aquilion 64 CT scanners. The acquired images were processed in the TeraRecon Aquarius Workstation (San Mateo, Calif) and the volume values were measured. MRI was performed on a 1,5T system (Signa, Voyager; GE Healthcare, WI, USA) using the body coil as a transmitter and a dedicated 16-channel phased-array receiver coil (Sentinelle Vanguard, Toronto, Canada). Diffusion weighted imaging (DWI) MRI examination was performed in the patients. Axial DWI MR imaging was performed using 2D, DW single-shot, dual spin echo-planar imaging (EPI) sequences (TR 6,000 ms; minimum TE; flip angle $90^{\circ}$; acquisition matrix: $128 \times 128$; reconstructed matrix: $256 \times 256$; FOV $25 \times 25 \mathrm{~cm}$; slice thickness: $5 \mathrm{~mm}$; NEX 4; slice gap: 0-1 mm. DWI was acquired at b-values of 0 and $1000 \mathrm{~s} / \mathrm{mm} 2$. Infarct volumes were calculated using the workstation (Volume Share 7.4.1) in the examinations.

Ethical committee approval was obtained from the Ethics Committee of Sakarya University Research and Training Hospital (approval number: 050.01.04/164, date: 02.10.2017).

\section{Statistical Analysis}

In the descriptive statistics of the data, mean, standard deviation, median minimum and maximum, frequency, and ratio values were used. The distribution normality of variables was tested with the Kolmogorov-Smirnov test. The Mann-Whitney U-test was used to analyze quantitative independent data. The Chi-square test was used in the analysis of qualitative independent data and the Fischer test was used when the conditions of the chi-square test were not met. $\mathrm{p}<0.05$ was considered statistically significant. The statistical analyzes were performed via the software of SPSS, version 27.0 (IBM Corp.; Armonk, NY, USA). 


\section{RESULTS}

This study involved a total of 31 (2.2\%) patients with TOBS among 1379 patients with stroke for 2,5 years in Sakarya, Turkey. Eighteen (58.1\%) were female and 13 (41.9\%) were male. (Table 1) The mean age of the study population was $69.0 \pm 12.1$ (42-97) years. Among the whole study population, 20 patients (64.5\%) had HT, 14 (45.2\%) had CAD, 13 (31.9\%) DM, 11 (35.5\%) CVD, 3 (9.7) had CHF, 2 (6.5\%) had AF (Table 1).

\begin{tabular}{|c|c|c|}
\hline & Number & Percentage \\
\hline \multicolumn{3}{|l|}{ Gender } \\
\hline Female & 18 & $58.1 \%$ \\
\hline Male & 13 & $41.9 \%$ \\
\hline \multicolumn{3}{|l|}{ Premorbid Disease } \\
\hline HT & 20 & $64.5 \%$ \\
\hline $\mathrm{DM}$ & 13 & $41.9 \%$ \\
\hline CAD & 14 & $45.2 \%$ \\
\hline $\mathrm{CHF}$ & 3 & $9.7 \%$ \\
\hline CVD & 11 & $35.5 \%$ \\
\hline $\mathrm{AF}$ & 2 & $6.5 \%$ \\
\hline \multicolumn{3}{|l|}{ Presenting Symptoms } \\
\hline Decreased level of consciousness & 15 & $48.4 \%$ \\
\hline Speech disorder & 9 & $29.0 \%$ \\
\hline Paresia and/or parestesia & 9 & $29.0 \%$ \\
\hline Ataxia & 5 & $16.1 \%$ \\
\hline Visual abnormalities & 5 & $16.1 \%$ \\
\hline Seizure & 1 & $3.4 \%$ \\
\hline \multicolumn{3}{|l|}{ NIHSS } \\
\hline Mild & 11 & $35.5 \%$ \\
\hline Moderate & 16 & $51.6 \%$ \\
\hline Severe & 4 & $12.9 \%$ \\
\hline \multicolumn{3}{|c|}{$\begin{array}{l}\text { HT: hypertension, DM: diabetes mellitus, CAD: coronary artery } \\
\text { disease, CHF: congestive heart failure, CVD: cerebrovascular } \\
\text { disease AF: atrial fibrillation, NIHSS: National Institutes of Health } \\
\text { Stroke Scores }\end{array}$} \\
\hline
\end{tabular}

The most common presenting symptom of TOBS was decreased level of consciousness $(n=15,48.4 \%) .9$ patients (29.0\%) had speech disorder, 9 patients $(29.0 \%)$ had paresia and/or parestesia, $5(16.1 \%)$ patients had ataxia, 5 patients $(16.1 \%)$ had visual abnormalities. One patient (a 84-year-old-woman) (3.4\%) had epileptic seizure as an initial symptom of TOBS (Table 1).

The patients were categorized into three groups according to NIHSS. $(0-6=$ mild, $7-15=$ moderate, $16-42=$ severe $)$ According to stroke severity, the groups were categorized as 11 (35.5\%) patients with mild stroke, 16 (51.6\%) patients with moderate stroke, and $4(12.9 \%)$ patients with severe stroke (Table 1).

The mean infratentorial infarct volume was $8.84 \pm 10.44$ $\mathrm{mm} 3$ (0.17-33.88). Supratentorial infarct volume was $15.11 \pm 22.32 \mathrm{~mm} 3$ (0.11-87.91).

Total of 31 patients of who 11 patients were admitted to neurology clinic, 5 patients were admitted to neurology clinic initially, when patients had worse clinically outcome they were admissions ICU from neurology clinic, 15 patients were direct admissions to ICU. (Table 2)

\begin{tabular}{|l|c|c|c|}
\hline \multicolumn{4}{|c|}{ Table 2. Number of the patients' with Top of the Basilar Syndrome } \\
hospitalized in neurology clinic, ICU and mortality rate
\end{tabular}

The average LOS in neurology clinic was 6.0 2 3.6 days. Twenty-one (67.7\%) patients needed to be in an ICU. The average LOS was in ICU was $40.8 \pm 40.3$ days. Patients admitted to the ICU had significantly higher the presence of DLC and visual abnormalities as an initial symptom, NIHSS, infratentorial infarct volume than patients admitted to the neurology clinic. $(\mathrm{p}=0.003, \mathrm{p}=0.008, \mathrm{p}=0.047)$ (Table 3) Thirteen patients (61.9\%) admitted to the ICU required MV. The mean duration of MV was $33.8 \pm 45.3$ 
days. The presence of DLC, ataxia, visual abnormalities as an initial symptoms, NIHSS, infratentorial infarct volume were higher among patients who required MV compared with who did not. ( $p=0.007, p=0.038, p=0.038, p=0.005$, $\mathrm{p}=0.005)$ The average timing of intubation was $16.1 \pm 24.9$ days (1-90). The mean duration of MV in this cohort was $33.8 \pm 45.3$ days (1-138). The mortality rate was 32.3 $\%(n=10) .8$ of 15 patients who were direct admissions to ICU, were died. 2 of 5 patients who were admissions ICU from neurology clinic, were died. (Table 2) NIHSS, LOS in clinic and ICU, the duration of MV were statistically high- er among patients who died from Top of the Basilar Syndrome in hospital compared with alive patients. $(\mathrm{p}<0.05)$ According to the evaluation of the stroke severity, the NIHSS score of patients who died was statistically higher than that of alive patients. $(p=0.007)$ The mortality rate was found to be higher in patients who had prolonged LOS in neurology clinic and ICU. $(p=0.015, p=0.008)$ It was determined that mortality rate was significantly increased in patients with prolonged duration of MV. $(\mathrm{p}<0.001)$ (Table 4)

\begin{tabular}{|c|c|c|c|}
\hline & $\begin{array}{c}\text { No admission to the ICU } \\
\mathrm{n} \text { (percentage) } \\
\text { Mean } \pm \text { SD }\end{array}$ & $\begin{array}{l}\text { The patients admitted the ICU" } \\
\text { n (percentage) } \\
\text { Mean } \pm \text { SD }\end{array}$ & $\mathrm{p}$ \\
\hline Age & $67.5 \pm 16.3$ & $69.8 \pm 9.9$ & 0.635 \\
\hline Female & $6(60.0 \%)$ & $12(57.1 \%)$ & 0.880 \\
\hline Male & $4(40.0 \%)$ & $9(42.9 \%)$ & \\
\hline \multicolumn{4}{|l|}{ Premorbid Disease } \\
\hline HT & $7(70.0 \%)$ & $13(61.9 \%)$ & 0.660 \\
\hline $\mathrm{DM}$ & $5(50.0 \%)$ & $8(38.1 \%)$ & 0.530 \\
\hline CAD & $5(50.0 \%)$ & $9(42.6 \%)$ & 0.709 \\
\hline $\mathrm{CHF}$ & $1(10.0 \%)$ & $2(9.5 \%)$ & 1.000 \\
\hline CVD & $5(50.0 \%)$ & $6(28.6 \%)$ & 0.244 \\
\hline $\mathrm{AF}$ & $1(10.0 \%)$ & $1(4.7 \%)$ & 1.000 \\
\hline \multicolumn{4}{|l|}{ Presenting Symptoms } \\
\hline Decreased level of consciousness & $1(10.0 \%)$ & $14(66.7 \%)$ & 0.003 \\
\hline Speech disorder & $4(40.0 \%)$ & $5(23.8 \%)$ & 0.353 \\
\hline Paresia and/or parestesia & $4(40.0 \%)$ & $5(23.8 \%)$ & 0.353 \\
\hline Ataxia & 0 & $5(23.8 \%)$ & 0.147 \\
\hline Visual abnormalities & $4(40.0 \%)$ & $1(4.7 \%)$ & 0.027 \\
\hline Seizure & 0 & $1(4.7 \%)$ & 0.123 \\
\hline NIHSS & $6.2 \pm 3.3$ & $10.8 \pm 5.0$ & 0.008 \\
\hline Infratentorial infarct volume & $5.2 \pm 9.7$ & $10.6 \pm 10.6$ & 0.047 \\
\hline Supratentorial infarct volume & $7.7 \pm 9.2$ & $18.6 \pm 25.9$ & 0.933 \\
\hline
\end{tabular}


Sakarya Med J 2021;11(3):639-646

AYAS et alk., The Prognosis of the Top of The Basilar Syndrome

\begin{tabular}{|c|c|c|c|}
\hline & $\begin{array}{l}\text { Exitus } \\
\mathrm{n}(\text { percentage) } \\
\text { Mean } \pm \text { SD }\end{array}$ & $\begin{array}{l}\text { Alive } \\
\mathrm{n}(\text { percentage) } \\
\text { Mean } \pm \text { SD }\end{array}$ & $\mathrm{p}$ \\
\hline Age & $72.5 \pm 8.8$ & $67.4 \pm 13.3$ & 0.279 \\
\hline Female & $4(40.0 \%)$ & $14(66.7 \%)$ & 0.160 \\
\hline Male & $6(60.0 \%)$ & $7(33.3 \%)$ & \\
\hline \multicolumn{4}{|l|}{ Premorbid Disease } \\
\hline HT & $6(60.0 \%)$ & $14(66.7 \%)$ & 0.717 \\
\hline $\mathrm{DM}$ & $5(50.0 \%)$ & $8(38.1 \%)$ & 0.530 \\
\hline CAD & $4(40.0 \%)$ & $10(47.6 \%)$ & 0.690 \\
\hline $\mathrm{CHF}$ & $1(10.0 \%)$ & $2(9.5 \%)$ & 1.000 \\
\hline CVD & $5(50.0 \%)$ & $6(28.6 \%)$ & 0.244 \\
\hline $\mathrm{AF}$ & $1(10.0 \%)$ & $1(4.7 \%)$ & 1.000 \\
\hline \multicolumn{4}{|l|}{ Presenting Symptoms } \\
\hline Decreased level of consciousness & $7(70.0 \%)$ & $8(38.1 \%)$ & 0.097 \\
\hline Speech disorder & $3(30.0 \%)$ & $6(28.6 \%)$ & 0.935 \\
\hline Paresia and/or parestesia & $2(20.0 \%)$ & $7(33 . \%)$ & 0.445 \\
\hline Ataxia & 0 & $5(23.8 \%)$ & 0.147 \\
\hline Visual abnormalities & 0 & $5(23.8 \%)$ & 0.147 \\
\hline Seizure & 0 & $1(4.7 \%)$ & 0.123 \\
\hline NIHSS & $13.5 \pm 5.6$ & $7.3 \pm 3.2$ & 0.007 \\
\hline Infratentorial infarct volume & $11.8 \pm 10.0$ & $7.5 \pm 10.6$ & 0.091 \\
\hline Supratentorial infarct volume & $21.1 \pm 26.1$ & $12.3 \pm 20.3$ & 0.499 \\
\hline LOS in neurology clinic & $2(20.0 \%)$ & $14(66.7 \%)$ & 0.015 \\
\hline LOS in ICU & $10(100 \%)$ & $11(52.4 \%)$ & 0.008 \\
\hline MV & $9(90.0 \%)$ & $4(19.0 \%)$ & 0.000 \\
\hline \multicolumn{4}{|c|}{$\begin{array}{l}\text { HT: hypertension, DM: diabetes mellitus, CAD: coronary artery disease, CHF: congestive heart failure, CVD: cerebrovascular disease AF: } \\
\text { atrial fibrillation, NIHSS: National Institutes of Health Stroke Scores, LOS: lenght of stay, ICU: intensive care unit, MV: mechanical ventila- } \\
\text { tion. }\end{array}$} \\
\hline
\end{tabular}

There was no significant differences between age, sex, presenting symptoms, premorbid diseases, infratentorial, supratentorial infarct volume and mortality. $(\mathrm{p}>0.05)$

\section{DISCUSSION}

There are widespread lesions of the temporal and occipital lobes, thalamus, midbrain, pons and cerebellum in TOBS. The incidence of the disease is not certain. In a study of 100 patients with ischemic stroke, TOBS was detected in 4 patients. ${ }^{2}$ In our study, patients with TOBS were detected in 31 of $1379(2.2 \%)$ all stroke patients within 2,5 years in Sakarya city. Voetsch et al. reported that 10 patients
(2.45\%) had distal basilar artery occlusive disease among 407 patients who had posterior circulation ischemia for 8 years. ${ }^{6}$ A study showed that most patients were older age (average 75 years). ${ }^{2}$ The mean age of patients with TOBS was $64.8 \pm 8.6$ in an other study. ${ }^{3}$ Similarly, the mean age of our study population was $69.0 \pm 12.1$ years. It was also reported in the study that the mean age of the patients with TOBS was younger (61 years). ${ }^{4}$ Voetsch et al. reported that men were more vulnerable to basilar artery occlusive disease than women. ${ }^{6}$ Female dominance is noticable in TOBS for limited studies. A study reported that number of female patients were higher than male patients (16:9), 
another study reported 16:14 female/male ratio. ${ }^{3,4}$ In our study, 18 (58.1\%) female patients were detected.

The disease's clinical course is usually characterized by visual, oculomotor disturbances, altered mental status, behavioral disorders, cerebellar disorders and hallucinations. ${ }^{8}$ Kuroğlu et al. reported that most common presenting symptoms of TOBS were motor deficite (\%53.3), loss of consciousness (46.6\%), visual/oculomotor symptoms (43.3\%) cerebellar dysfunction (40.0\%), behavioral disorder (26.6\%) and speech disorder (16.6\%). ${ }^{4}$ A study with 25 patients with TOBS, the commonest clinical manifestations were: motor deficit (68\%), abnormal eye movements (48\%), cerebellar dysfunction (40\%), alteration of the level of consciousness (32\%), visual field defects (20\%), pupil anomalies (16\%). ${ }^{3}$ Decreased level of consciousness $(n=15$, $48.4 \%$ ) was the most common presenting symptom, in our study. Speech disorder, paresia and/or parestesia, ataxia, visual abnormalities, seizure were other initial symptoms, respectively. Seizure is a rare presenting symptom. In the literature, a 23-year-old patient who had seizure as an initial symptom of TOBS was reported. ${ }^{9}$ In our study, a 84-year-old woman was diagnosed with TOBS whose presenting symptom was epilectic seizure.

There are conventional vascular risk factors for ischemic stroke. Basilar artery disease had a high co-morbidty of these risk factors. ${ }^{6} \mathrm{HT}$ is the most prevalent risk factor for stroke, has been reported in about $64 \%$ of patients with stroke.10,11 Also HT was the most frequent (66.7\%) risk factor in basilar artery occlusive disease. ${ }^{6} \mathrm{DM}$ is a recognized independent risk factor for stroke and is associated with higher morbidity and mortality. ${ }^{12}$ Stroke and CAD are risk factors for one another. ${ }^{13} \mathrm{AF}$ is an important risk factor for ischemic stroke since it associates with a 5-fold higher risk of stroke compared with the general population. ${ }^{14}$ In a study, HT (64\%), CVD (28\%), smoking (28\%), DM (24\%) and AF (20\%) were most frequently associated with TOBS. ${ }^{3}$ Similarly, HT (64.5\%) was the most common disease in premorbid histories in our study. CAD (45.2\%),
DM (41.9\%), CVD (35.5\%), CHF (9.7\%), AF (6.5\%) were other disease in premorbid medical histories. The patients with TOBS had no significant difference between premorbid diseases and mortality, in our study.

Stroke is the second leading cause of death. The mortality of ishemic stroke patients was found $52.7 \%$ in a study. ${ }^{15}$ Many factors increase mortality of patients with ischemic stroke. Impaired consciousness is independent predictors of mortality for severe ischemic stroke during the acute stage. ${ }^{16}$ But, according to presenting symptoms, there was no significant difference between decreased level of consciousness and mortality of TOBS which is a rare stroke, in our study. The NIHSS score of patients who died was statistically higher than that of other patients. $(p<0.005)$. Fracalanza et al. reported that low NIHHS score of patients with basilar artery occlusion were associated with good clinical outcome. ${ }^{17}$ The mortality rate of this study was $29.6 \% .^{17}$ Mortality of patients with TOBS was $8 \%$ in a study. ${ }^{13}$ In our study, high mortality rate was detected (32.3\%). Similarly, 88 patients with basilar artery stenosis or occlusion had poor outcome in $54 \%$ cases as an severe disability or death. ${ }^{18}$ Labauge et al. reported that the mortality rate was $86 \%$ in basilar artery occlusion. ${ }^{19}$ Another study about basilar artery occlusive disease reported that involvement of the distal side of artery had an increased risk of death and disability.

LOS in hospital is an significant factor for prognosis of the disease. According to the evaluation of the ischemic stroke patients, LOS in ICU and the duration of MV of patients who died was statistically higher than alive. ${ }^{20}$ The mean LOS in ICU was $7 \pm 2$ days, length of MV was $5 \pm 2$ days and mortality rate of stroke was $59.25 \%$ were reported in a study. ${ }^{21}$

The mortality of ischemic stroke patients admitted to ICU within 30 days of hospitalization in the study period was $21 \%$ and MV was associated with 5-fold higher mortality.20 We have noted that our LOS in neurology clinic and 
ICU were higher than the studies about ischemic stroke, and mortality was higher. But many factors lead LOS in hospital and mortality. Also, TOBS is a rare stroke syndrome. There are not large data base about prognosis and mortality of the disease. Therefore our datas were compared with literature of other stroke types and limitied TOBS article.

\section{Study Limitations}

The limitations of our study is absent of computed tomography angiography, magnetic resonance angiography, and digital subtraction angiography. Most of patients had no angiography, because of some patients had renal dysfuntion, some patients had contrast allergy, some were died in a short-time. Neurovascular findings will add an important informations about prognosis of disease. There is a need for larger and more detailed studies to elucidate the factor that determine the prognosis of the disease.

Our study aimed to investigate relationship between clinical and radiological parameters and mortality of the disease. This study is significant because our cohort had an important series of TOBS. No study has yet investigated the relationship between clinical and radiological parameters and mortality in literature.

There is a critical importance of early diagnosis in emergency and quickly admission from the emergency department to ICU, because of high mortality of TOBS.

This study is significant because of its pioneering role in the investigation of prognosis in patients with TOBS for the first time in Sakarya city and Turkey. It is important to determine effective parameters in order to prognose TOBS which is a rare stroke syndrome. Initial symptoms, NIHSS, infratentorial infarct volume are important for ICU admission and MV, while NIHSS, LOS in clinic and ICU, the duration of MV are important parameters for mortality. The criterias related to mortality are important for more effective approach to patients with TOBS.

\section{Ethics Committee Approval}

Ethical committee approval was obtained from the Ethics Committee of Sakarya University Research and Training Hospital (approval number: 050.01.04/164, date: 02.10 .2017$)$.

\section{Peer-review}

Externally peer-reviewed.

\section{Informed Consent}

It was not considered necessary to get consent from the patients because the study was a retrospective data analysis.

Author contributions ZÖA, DK, KA provided author's contributions concepts. DK, ZÖA, involved in design. ZÖA, DK, contributed materials. ZÖA, DK, KA collected the data. ZÖA, CT, KA performed literature search. ZÖA, DK, KA wrote the manuscript. ZÖA, DK, KA involved in critical reviews.

\section{Conflict of Interest}

No conflict of interest was de- clared by the authors.

\section{Financial Disclosure}

The authors declared that this study has received no financial support. 
Sakarya Med J 2021;11(3):639-646

AYAS et alk., The Prognosis of the Top of The Basilar Syndrome

\section{References}

1. Caplan LR. 'Top of the basilar' syndrome. Neurology 1980;30(1):72-79.

2. Barkhof F, Valk J. "Top of the basilar" syndrome: a comparison of clinical and MR findings. Neuroradiology 1988;30(4):293-298.

3. Usón-Martín M, Gracia-Nava M. Top of the basilar artery syndrome: clinico-radiological aspects of 25 patients. Rev Neurol 1999;28(7): 698-701.

4. Kıroğlu Y, Onur S, Herek D, Agladıoglu K, Teke E, Citısl V. Neuroimaging evaluation of non-aneurismatic 'Top of the Basilar' Syndrome. J Neurol Sci \Turkish囚 2016;33(2):286295.

5. Caplan LR, Wityk RJ, Glass TA, Tapia J, Pazdera L, et al. New England medical center posterior circulation registry. Ann Neurol 2004;56(3):389-398.

6. Voetsch B, DeWitt LD, Pessin MS, Caplan LR. Basilar artery occlusive disease in the New England Medical Center posterior circulation registry. Arch Neurol 2004;61(4):496-504.

7. Caplan LR, Chungh CS, Withy RJ, Glass TA, Tapia J, PAzdera L, et al. New England Medical Center posterior circulation stroke registry: I. Methods, data base, distribution of brain lesions, stroke mechanism and outcomes. J Clin Neurol 2005; 1(1):14-30.

8. Warlow C, vanGijn J, Dennis M, Wardlaw J, Bamford J, Hankey G, et al. Which arterial territory is involved? In: Sugden M, editor. Stroke: practical management. 3rd ed, Blackwell Publishing: USA; 2008. p 151.

9. Matsuo K, Chihiro F, Fuse I, Nakajima M, Takada M, Miyata K. Top of the Basilar Syndrome in a young adult initally presenting with a convulsive seizure. Intern Med 2011;50:14251428.

10. Feigin VL, Norrving B, Mensah GA. Global burden of stroke. Circ Res. 2017;120:439-448. 11. O'Donnell MJ, Xavier D, Liu L, Zhang H, Chin SL, Rao-Melacini P, et al. Risk factors for ischaemic and intracerebral haemorrhagic stroke in 22 countries (the INTERSTROKE study): a case-control study. Lancet. 2010;376:112-123.

12. Shou J, Zhou L, Zhu S, Zhang X. Diabetes is an Independent Risk Factor for Stroke Recurrence in Stroke Patients: A Meta-analysis. J Stroke Cerebrovasc Dis. 2015;24:1961-1968.
13. Dichgans M, Malik R, König IR, Rosand J, Clarke R, Gretarsdottir S, et al. Shared genetic susceptibility to ischemic stroke and coronary artery disease - a genome-wide analysis of common variants. Stroke 2014;45(1):24-36.

14. Kannel WB, Wolf PA, Benjamin EJ, Levy D. Prevalence, incidence, prognosis, and predisposing conditions for atrial fibrillation: population-based estimates. Am J Cardiol 1998; 82: $2 N-9 N$.

15. Kaplan Y, Kamışl Ö, Kamışıl S, Özcan C. Mortality-releted factors in ischemic patients 80 years of age older. Turkish Journal of Cerebrovascular Disease 2014;20(1): 7-12.

16. Lan MY, Wu SJ, Chang YY, Chen WH, Lai SL, Liu JS. Neurologic and non-neurologic predictors of mortality in ischemic stroke patients admitted to the intensive care unit. J Formos Med Assoc. 2006;105(8): 653-658.

17. Francalanza I, Ciacciarelli A, Caragliano AA, Casella C, Cotroneo M, Dell'Aera c, et al. Acute stroke treatment in patients with basilar artery occlusion: A single-center observational study Cerebrovasc Dis Extra 2019;9:90-97.

18. Devuyst G, Bogousslavsky J, Meuli R, Moncayo J, de Freitas G, van Melle G. Stroke or transient ischemic attacks with basilar artery stenosis or occlusion: clinical patterns and outcome. Arch Neurol. 2002;59:567-573.

19. Labauge R, Pages M, Marty-Double C, Blard JM, Boukobza M, Salvaing P. Occlusion of the basilar artery: a review with 17 personal cases [in French]. Rev Neurol (Paris). 1981; 137:545-571.

20. Golestanian E, Liou J-I, Smith MA. Long-Term Survival in Older Critically III Patients with Acute Ischemic Storke Critical care Medicine 2009;37(12):3107-3113.

21. Consales G, Natale V, Sardu A, Grechi S, Angiolini P, De Gaudio A. Stroke treatment and outcome in ICU. Crit Care 2002;6:P50. 